\title{
Levéltár-pedagógiai lehetőségek és tapasztalatok a Budapesti Múszaki és Gazdaságtudományi Egyetemen
}

A levéltár-pedagógia fogalmának a szakmai köztudatban történő hazai megjelenése és az ilyen programokat megvalósító intézmények munkatársainak első beszámolói óta kerestük a lehetőséget hasonló foglalkozások meghonosítására a BME Levéltárban is. Egyrészt felismertük, hogy az önreprezentáció szempontjából fontos ennek a munkaterületnek (és egyben szolgáltatásnak) a fejlesztése is, ${ }^{1}$ másrészt úgy gondoltuk, hogy a hagyományos közmüvelődési feladatok és színterek (kiállítások, levéltári napok stb.) közül a levéltár-pedagógiai foglalkozások adhatják meg leginkább az élményszerü ismeretszerzés és tanulás lehetőségét. ${ }^{2}$

Az órák tartására alkalmas előadó- vagy oktatótér nem áll rendelkezésünkre (bár a levéltár-pedagógiai foglalkozásokat nem feltétlenül kell levéltárban rendezni), emellett a munkatársi létszám is behatárolja az erre fordítható energiáinkat. ${ }^{3}$ Ezért elsősorban olyan lehetőségeket kerestünk és használtunk/használunk ki, amelyek valamilyen egyetemi rendezvényhez köthetők különböző formákban. Emellett nem csak a gyermek- és ifjúsági korosztály részére kínált, épp ezért talán nem is a szorosan vett levéltár-pedagógia ${ }^{4}$ körébe sorolható alkalmak azok a kulturális, illetve ismeretterjesztő tömegrendezvények (Múzeumok Éjszakája, Kulturális Örökség Napjai, Kutatók Éjszakája, Emlékhelyek Napja), amelyek szélesebb látogatói közönséget vonzanak a Müegyetemre. Ezek az események mind alkalmasak voltak arra az elmúlt években, hogy a levéltár minden korosztály számára bepillantást biztosítson akár szó szerint a raktárba, akár átvitt értelemben a forrásokkal való munkába, és ezen keresztül az egyetem múltjának és hagyományainak megismerésébe.

A rendezvényekbe rendszeresen bekapcsolódó könyvtáros kollégákkal együtt úgy tapasztaltuk, hogy a Múzeumok Éjszakája nyújt legkevésbé érvényesülési lehetőséget a múegyetemi programok számára, mivel hatalmas a fóvárosi kínálat. Ráadásul az egyetem vezetése is elsősorban más rendezvényeken

${ }^{1}$ Simonkay Márton: Levéltár-pedagógia ma és holnap. = Levéltári Szemle, 67. évf. 2017. 4. sz. 50-65. p.

2 A szerző korábban két alkalommal tartott előadást a témában: a Magyar Levéltárosok Egyesülete 2017. évi vándorgyülésén, valamint a Magyar Felsőoktatási Levéltári Szövetség 2018. évi hasonló rendezvényén.

3 Jelenleg négy fő dolgozik a BME Levéltárban, ebből egy levéltárvezető, egy pedig részmunkaidős munkatárs nem szakirányú középfokú végzettséggel.

${ }^{4}$ Simonkay Márton: Levéltár-pedagógia ma és holnap. = Levéltári Szemle, 67. évf. 2017. 4. sz. 50-65. p. 
(pl. Emlékhelyek Napja) számít a könyvtár és a levéltár feladatvállalására. ${ }^{5}$ A Kulturális Örökség Napjai - az egyetemi campus múemléki épületeinél fogva mindig érdeklődést váltanak ki, ahol elsősorban az építéstörténet és az épületek titkai iránt fogékonyak a résztvevők. Külön levéltári programot ezekre az alkalmakra nem is feltétlenül tervezünk, inkább az előadásokat tartó és sétákat vezető építész és történész kollégák hívják fel a figyelmet a nálunk található vonatkozó forrásokra. A Kutatók Éjszakája szintén nagyon jó lehetőség, hiszen az egyetem oktatói által végzett érdekes kutatások tömegeket vonzanak minden szeptember végén a BME számos épületébe és laborjába. Ennek ellenére is érdemes saját programot tervezni, amire többször volt is példa. ${ }^{6}$

Nem csak a tömegrendezvények kínálnak alkalmat a levéltárat bemutató, élményszerü ismeretszerzést biztosító programokra. A müegyetemi könyvtár rendszeresen tart, elsősorban a XI. kerület nyugdíjas közösségeinek, könyvtári és egyetemi sétákat. Ebben eddig még nem vettünk részt, azonban rájuk is érdemes figyelmet fordítani, hiszen ők más megközelítésből fogékonyak a levéltárról szóló ismeretszerzésre, illetve ez jól illeszkedik az élethosszig tartó tanulással kapcsolatos programokhoz. ${ }^{7}$

A levéltár fenntartójának oktatási intézmény jellege természetszerúleg adná az itt őrzött anyag (felső)oktatásban történő hasznosulását. Ez egy elsősorban müszaki és természettudományi képzést biztosító egyetemen nem magától értetődő, ezzel együtt a Gazdaság- és Társadalomtudományi Kar korábban múködő Tudományfilozófia és Tudománytörténet Doktori Iskola képzési programjának keretében évente egy-egy alkalommal lehetôség nyílt doktorandusz hallgatók fogadására, akik elsősorban a tudománytörténet müveléséhez hasznosítható forrásokkal ismerkedtek meg nálunk.

A középfokú oktatásban résztvevőkkel még nincsen tapasztalatunk, nem kezdeményeztünk kapcsolatfelvételt középiskolákkal, elsősorban kapacitásproblémák miatt. Ugyanakkor egyedi megkeresésektöl nem zárkózunk el, több témakörben

${ }^{5}$ A BME 2016-ban, az 1956-os forradalom és szabadságharc 60. évfordulóján nyerte el a történelmi emlékhely címet, és 2017-ben csatlakozott az Emlékhelyek Napját megtartó intézmények közé. Ennek keretében a nemzeti és történelmi emlékhelyek szerte az országban egy szombati napra megnyílnak és változatos programokat kínálnak. A Műegyetem eddig filmvetítést, kiállítást, illetve saját fejlesztésü mobiltelefonos applikáció segítségével zajló programot kínált - mindegyiket levéltári részvétellel, tartalommal.

${ }^{6}$ Már az első alkalom 2012-ben nyilvánvalóvá tette, hogy a forrásokba történő bepillantás és az aktivitásra épülő egyetemtörténeti kvízek, puzzle játékok stb. valóban élményt adnak - korosztálytól függetlenül. Egy másik évben a könyvtárban dolgozó történész kollégánk nyújtott betekintést kutatásaiba, amelyeket a nálunk őrzött levéltári források alapján végzett. Egy következő alkalommal a levéltár egyik munkatársa egyetemtörténeti sétát tartott, és arra is volt példa, hogy más levéltár munkatársainak bevonásával szerveztünk közérdeklődésre számot tartó beszélgetős programot.

${ }^{7}$ Lásd még Rácz Attila - Mautner Zoltán: Budapest Főváros Levéltára levéltár-pedagógiai foglalkozásai. http://ujkor.hu/content/bfl-leveltar-pedagogia (2019. március 9.) 
gondolkozunk, amelyek rugalmasan, az adott korosztályhoz, az iskola jellegéhez, illetve a tanári kérésekhez igazíthatók. A Budapest Főváros Levéltárában kidolgozott tematikákhoz hasonlóan mi is többféle foglalkozástípust tartunk megvalósíthatónak, ezek: a műegyetemi oktatás és az egyetemi polgárok mindenkori életének levéltári források alapján történő megismertetése; az 1956-os müegyetemi események felidézése (akár az egykori helyszíneket bemutató campussétával egybekötve); illetve az iratkezeléssel kapcsolatos iskolarendszerü vagy egyéb oktatásban résztvevők számára az irat életciklusának utolsó állomását jelentő levéltár müködésének és az egyetemi iratkezelésben betöltött szerepének bemutatása. Ilyen óra megtartására eddig egyetlen alkalommal került sor, egy ügyviteli ismereteket oktató szakközépiskolából érkeztek tanulók, akik számára a levéltári raktár egyben oktatótérré is vált. Emellett az 1956-os témakörben számos kiaknázatlan lehetőség látszik, amelyet felerősít az egyetemnek az 1956-os forradalomban és szabadságharcban betöltött szerepét elismerő történelmi emlékhely címe. Emiatt nemcsak az októberi időszak adhat lehetőséget számunkra levéltár-pedagógiai foglalkozások megtartására, hanem a májusi Emlékhelyek Napja is.

Az eddig ismertetettek mellett nem véletlenül maradt utoljára az alapfokú oktatásban résztvevőkkel való kapcsolatunk. Rendszeres, szervezett formában az ő számukra biztosítunk ugyanis klasszikus levéltár-pedagógiai programot, ráadásul szó szerint helyben, azaz a raktárunkban. A Mủegyetem 2015 óta szervez tudományos nyári gyerektábort BME Gyerekegyetem címmel, amelyben intézményünk a kezdetektől részt vállalt. A tábor célja, hogy az általános iskolás diákok kíváncsiságát egy nagyon fogékony életkorban próbálják felkelteni a müszaki és természettudományok iránt. A Gyerekegyetem igyekszik mindazokból a tudományterületekből, amelyeket a BME oktató-kutatói és közösségei művelnek, minél többet megmutatni az egyetem életébe betekintést nyerő gyerekek számára, hogy érzékelhessék a tudományok sokszínűségét, a felfedezés örömét, a kutatói életpálya szépségét, a gyakorlati életben való alkalmazást. ${ }^{8}$ Az egyhetes nyári tábor, amelyet teljes egészében a BME polgárai biztosítanak (infrastruktúra, szervezés, tartalom, felügyelet), előadásokból, sok-sok kísérlet és gyakorlati feladat elvégzését biztosító szemináriumokból, sport- és szabadidős programokból, valamint projektfeladat megoldásából áll, és jelképes diplomaátadó ünnepséggel zárul. A szinte jelképes önköltségen túl számos szponzor biztosítja a megvalósulást.

Az első évben az egyhetes táborban összesen 300 gyermek vett részt, azóta korosztályi bontásban (2-5. osztályosok és 6-8. osztályosok), kétszer egyhetes turnusban évente közel 700-an részesei a tudományos programsorozatnak. Már az első rendezvény átütő sikere, az azóta is töretlen óriási érdeklődés, a többszörösen

${ }^{8}$ Dallos Györgyi - Farkas László - Hornyánszky Gábor - Lángné Lázi Márta - Lukács Mónika: Új fogalom robbant be a köztudatba: BME Gyerekegyetem. = Magyar Tudomány, 2017. 7. sz. $875-884$. p. 
telített várólisták, valamint a programokat megtartó müegyetemi oktatók, munkatársak és hallgatók lelkesedése egyértelmúvé tette mind a szervezők, mind az egyetem vezetése számára a folytatást és egyben a bővítést is. ${ }^{9}$ A kezdeményezés mára igazi közös mủegyetemi programmá, egyben az egyetemi utánpótlás és tehetséggondozás első érintkezési pontjává nőtte ki magát, a müegyetemi oktatók mellett pedig a tavalyi óraadók között szerepelt Navracsics Tibor oktatásért, kultúráért, ifjúságpolitikáért és sportért felelős uniós biztos is, aki a gyermekjogokról tartott előadást.

Ebben a rendezvénysorozatban találta ki programját és szerezte meg föbb levéltár-pedagógiai tapasztalatait intézményünk is, ahová a foglalkozás keretében kb. 100 gyermek jut el évente. ${ }^{10}$ Eddigi foglalkozásainkon az iratokkal való közvetlen találkozás reményeink szerint olyan többletet biztosított a gyerekek számára, amely élményszerüvé tette az ismeretszerzést mind a Mủegyetemről, mind az érintett történelmi korokról és eseményekröl, valamint fejlesztette a kritikai gondolkodást és a szövegértést. A táborban való részvételünknek éppen ez volt az egyik célja. A bekapcsolódásunk egyúttal a fenntartó egyetem számára is jelzés, hogy a levéltár természetes része az intézménynek, teljes mértékben betagolódik a szervezetébe és ott van a mindennapokban, munkánknak és szolgáltatásainknak pedig nemcsak közvetlenül az egyetemi szervezeti egységek felé, hanem a társadalom felé is látható a hasznosulása.

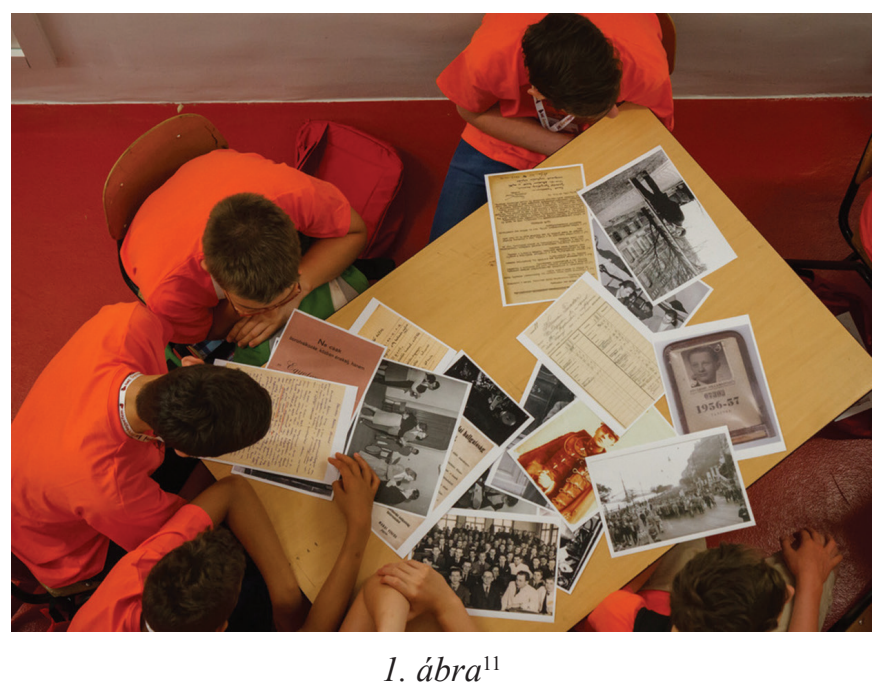

${ }^{9}$ Ezt szolgálják a két tábor közötti őszi és tavaszi hónapokban tartott Gyerekegyetem Plusz előadások vagy a pontgyüjtő rendszer, amely hosszabb távon is a BME-hez kapcsolja a gyerekegyetemistákat. Minderről itt lehet tájékozódni: http://gyerekegyetem.bme.hu (2019. április 8.)

${ }^{10} 2015$ és 2018 között összesen 20 csoport, mintegy 400 gyermek járt a levéltárban.

${ }^{11}$ A tanulmányban közölt képek forrása: http://gyerekegyetem.bme.hu (2019. április 8.) 
A Gyerekegyetem napirendje szerint 9 és 17 óra között zajlanak a foglalkozások, amelyeken a görög ábécé betüiröl elnevezett 20-25 fös tankörök vesznek részt. A kezdetektől csak felső tagozatosokban gondolkodtunk, azaz a Gyerekegyetem második hetében vállalunk órákat (általában 4-5 csoport jut el a levéltárba a párhuzamosan zajló szemináriumi kínálatból). ${ }^{12}$ Nagy kihívást jelentett számunkra, hogy az alapvetően természettudományos érdeklődésü 9-14 éves gyerekeknek hogyan mutassuk be a levéltárat és feladatait úgy, hogy rávilágítsunk az intézménynek az egyetemi múltőrzésben és közösségépítésben betöltött szerepére, annak jelentőségére is. Mindezt úgy, hogy érzékelhető különbség van az 5 . és a 8. osztályos csoportok között (a tankörök összeállításakor a szervezők az életkor szempontjából törekedtek a homogenitásra, így minél jobban igazodni lehet a csoport érdeklődéséhez, tempójához), miközben csak egy programmal tartjuk meg a levéltári szemináriumokat.

A tapasztalataink alapján évente frissülő programjaink kidolgozásakor mind az időtartam, mind a rendezvény jellege egyfajta kötöttséget jelent. Olyan óratervekre van ugyanis szükség, amelyek teljes tartalma belefér 45 percbe és maximálisan alkalmazkodnak a rendezvény jellegéhez, azaz a hangsúly a személyes tapasztalásra, a mindenki számára elérhető manuális munkára, az alkotási lehetőségre, az anyagokhoz való hozzáférésre került.

2015-ben, az első alkalommal egy klasszikus ismertető foglalkozást tartottunk Irány a múlt! Avagy a Google előtti keresés címmel. A 45 perces szemináriumok két részböl álltak, amelyek közül mindkettőben számítottunk a gyerekek aktív részvételére. Az első 20 percben olyan kérdéseket tettünk fel, amelyekre adott válaszokból ők maguk fogalmazhatták meg, mi a levéltár, hogyan kerülnek be az iratok, illetve mi történik velük a feldolgozástól kutatásig. A beszélgetés közben így olyan fogalmakat is megtanulhattak, mint az iratkezelési szabályzat, a fond, az adatvédelem vagy az iratfolyóméter. Arra is kíváncsiak voltunk, hogyan fogalmazzák meg az intézmény létjogosultságát, jelentőségét az egyetemen. A tapasztalatok alapján a levéltár fogalmával tisztában voltak, értették a múzeum, könyvtár és levéltár közötti különbségeket. Példák alapján azt is jól kiválasztották, hogy milyen iratokat, fotókat, terveket stb. őrzünk egyetemi levéltárként (ezeket az általános tapasztalatokat azóta minden évben megerősítik a gyerekek). A szeminárium második részében az egyetemi tanév történéseinek időbeli rendjét tudták rekonstruálni irat- és fotómásolatok segítségével. ${ }^{13} \mathrm{~A}$ feladat során nemcsak egyetemi fogalmakat ismertek meg (pl. szigorlat, rektor, szakdolgozat stb.),

${ }^{12}$ Ld. még Simonkay Márton: Levéltár-pedagógia ma és holnap. = Levéltári Szemle, 67. évf. 2017. 4. sz. 50-65. p.

${ }^{13}$ Ezek között voltak müegyetemi hallgatói törzskönyvek (pl. Oláh György Nobel-díjas kémikus, a BME egykori hallgatója vegyészmérnöki tanulmányait igazoló oldala), hallgatói eskü, kollégiumi életkép, ballagási bál meghívója, diplomaterv kiadása, felvételről szóló hivatalos értesítés vagy éppen egy öregdiák-találkozó fotója. 
hanem magának az egyetemi tanulmányoknak a rendjét is. Az óra végén egyetemtörténeti kvízt osztottunk ki, amelyet kiértékelve a győztes a családja kíséretében térhetett vissza egy részletesebb levéltári bemutató látogatásra.

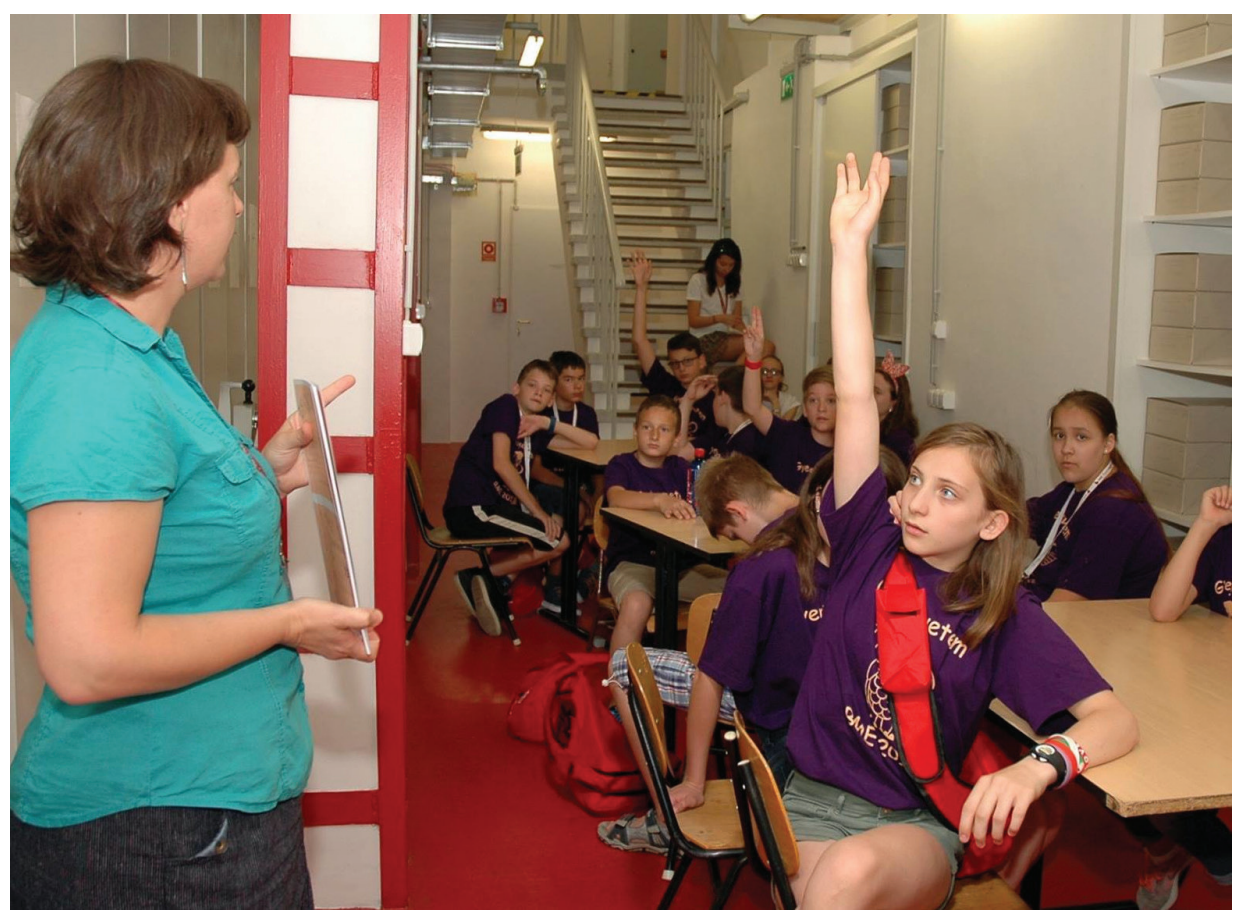

2. ábra

2016-ban a Retró Mủegyetem címü órán a levéltári forrásokra (közte sok fotóra) támaszkodva egy régi diák átlagos napját idézhették fel a gyerekegyetemisták a reggeli felkeléstől az egyetemre bejutáson, előadásokon való részvételen és menzai étkezésen át a szórakozásig és a vizsgázásig (a források között szerepelt pl. 1960-as évekbeli kollégiumi szobafotó, 1956-os villamosbérlet, 1944-es menza étrend is). A tapasztalatok szerint a gyerekek figyelmesen és számunkra meglepő részletekbe menően tanulmányozták a régi iratok és fotók másolatait.

Ebben az évben fizikai aktivitással is kiegészült a program: az órák végén a tömörállványzat múködését is kipróbálhatták a gyakorlatban. 


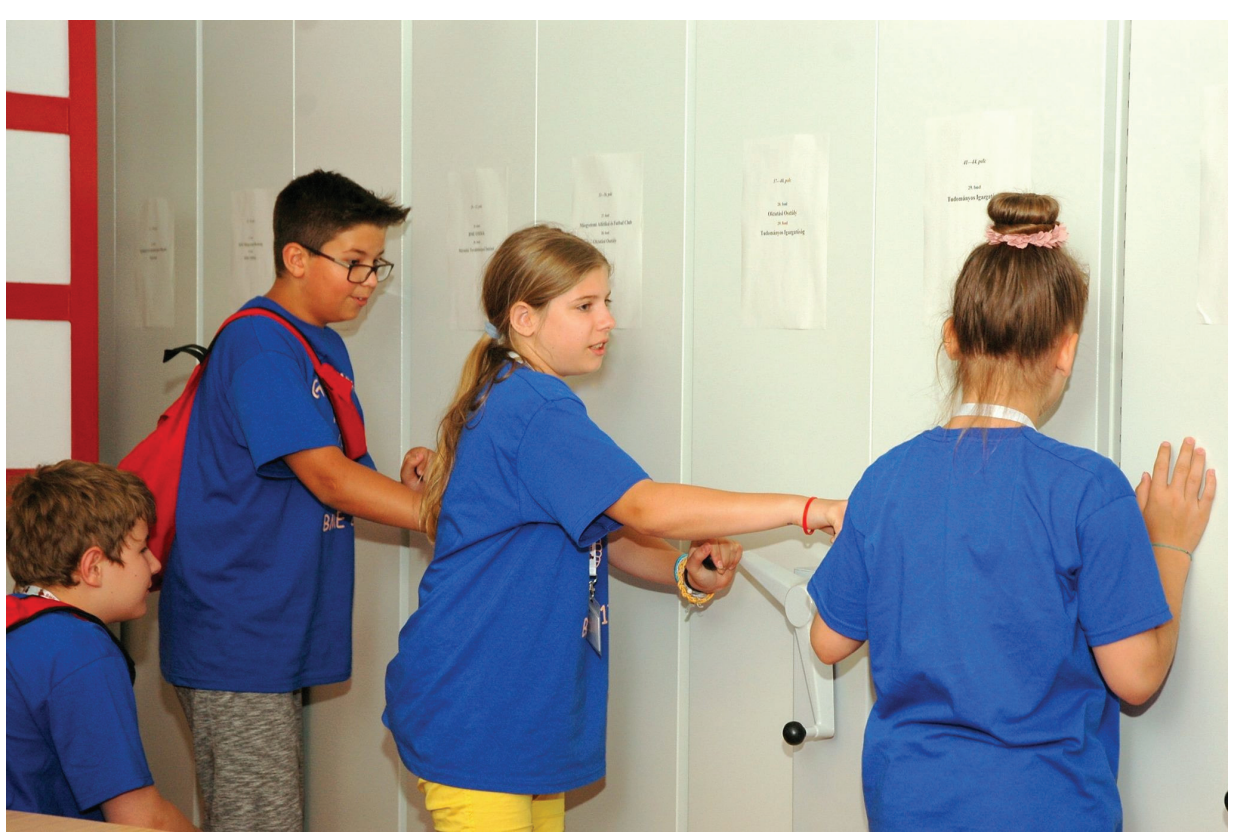

3. ábra

2017-ben Levéltitkok címmel egykori hallgatóktól fennmaradt leveleket elemeztünk a gyerekekkel, itt elsősorban történelmi eseményekre, helyzetekre tudtak következtetni a forrásokból (pl. első világháborús katonahallgató tábori lapját vagy egy szerencsejátékon ért, egyébként Trianon utáni menekült diák levelét olvasták el; itt már maga a kézírásos levél megtapasztalása és kisilabizálása is az átadható élmény része). A történelmi ismereteik bővítésén kívül korabeli megszólításokat és írásmódot is felfedezhettek a fennmaradt levelekben. Ebben az évben kísérletet tettünk a közösségi média felhasználására is, zárt Facebookcsoportot indítottunk további levelek megosztására, ám - az ismert trendeket megerősítve - azt tapasztaltuk, hogy már nem ez a gyerekek által leggyakrabban használt kapcsolattartási felület. 


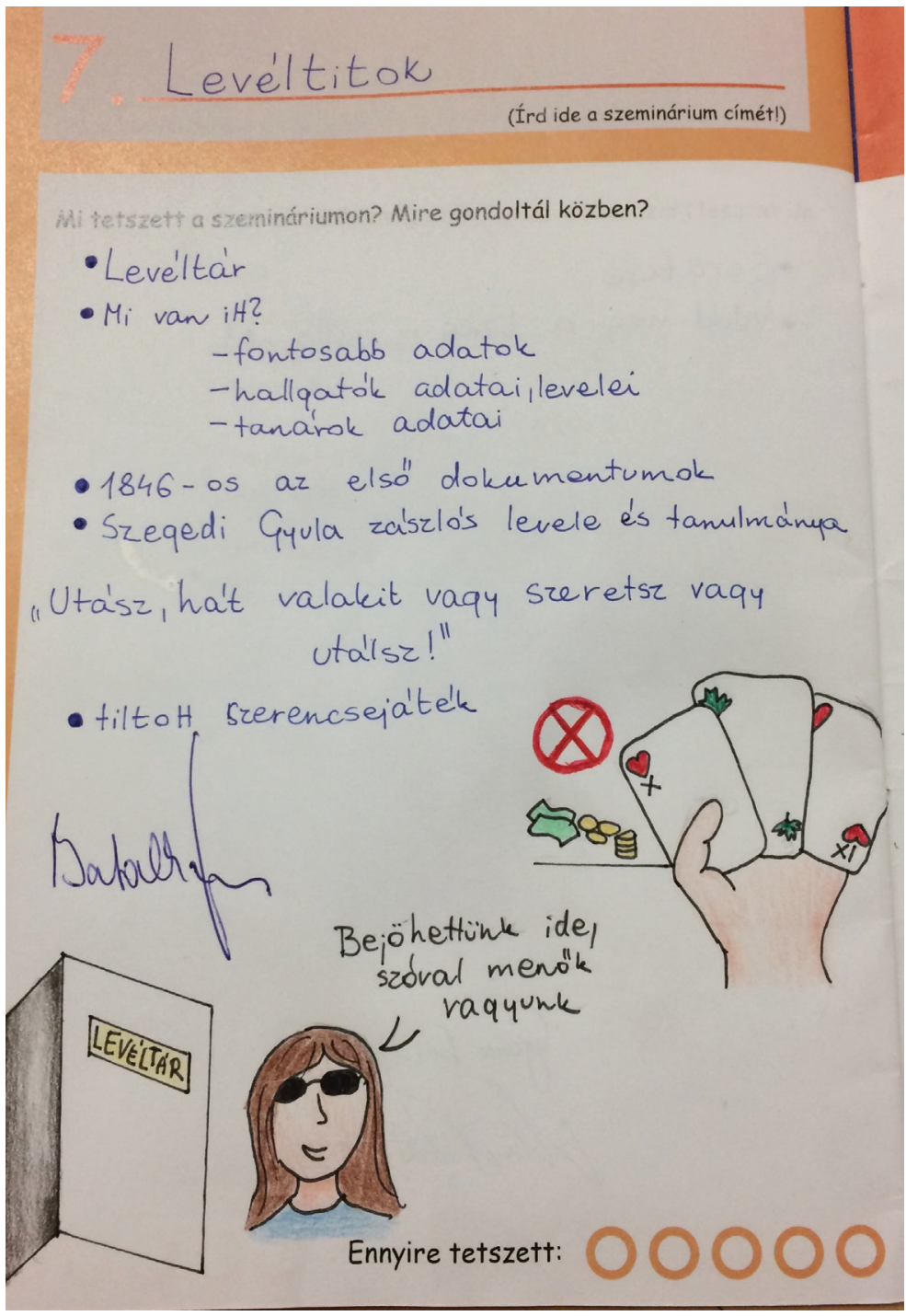

4. ábra

2018-ban az 1848-1849-es forradalom és szabadságharc 170. évfordulójára emlékezve az egykori elődintézmény, a József Ipartanoda hallgatói által 1848 áprilisában megfogalmazott 12 pontot elemeztük végig a gyerekekkel. Milyen volt a müszaki felsőoktatás a 19. század közepén, mi történt az ipartanoda diákjaival - megállítva az 1848. március 15-i nap forgatókönyvét egy ponton -, mit miért követeltek, és mi valósult meg az általuk kért pontokból - ezekre a kérdésekre kerestük közösen a válaszokat. Ezt követően arra kértük őket, hogy 
fordítsák le a megismert követeléseket a mai viszonyokra, azaz reagáljanak saját koruk problémáira, fogalmazzák meg, mit kívánnak a gyerekegyetemisták 2018-ban. A szó szerint összekiabált ötletekből kirajzolódott új 12 pontot a hetet lezáró diplomaosztón a teljes tábor előtt bemutatták. ${ }^{14}$ Ebben az évben első alkalommal lehetővé tettük, hogy az 1848 márciusi eseményekről szóló jelentés eredeti példányát is megnézhessék a gyerekek (kesztyüben, felügyelet mellett), hogy azt is megtapasztalhassák, milyen egy egyetlen példányban létező 170 éves dokumentumot kézben tartani.

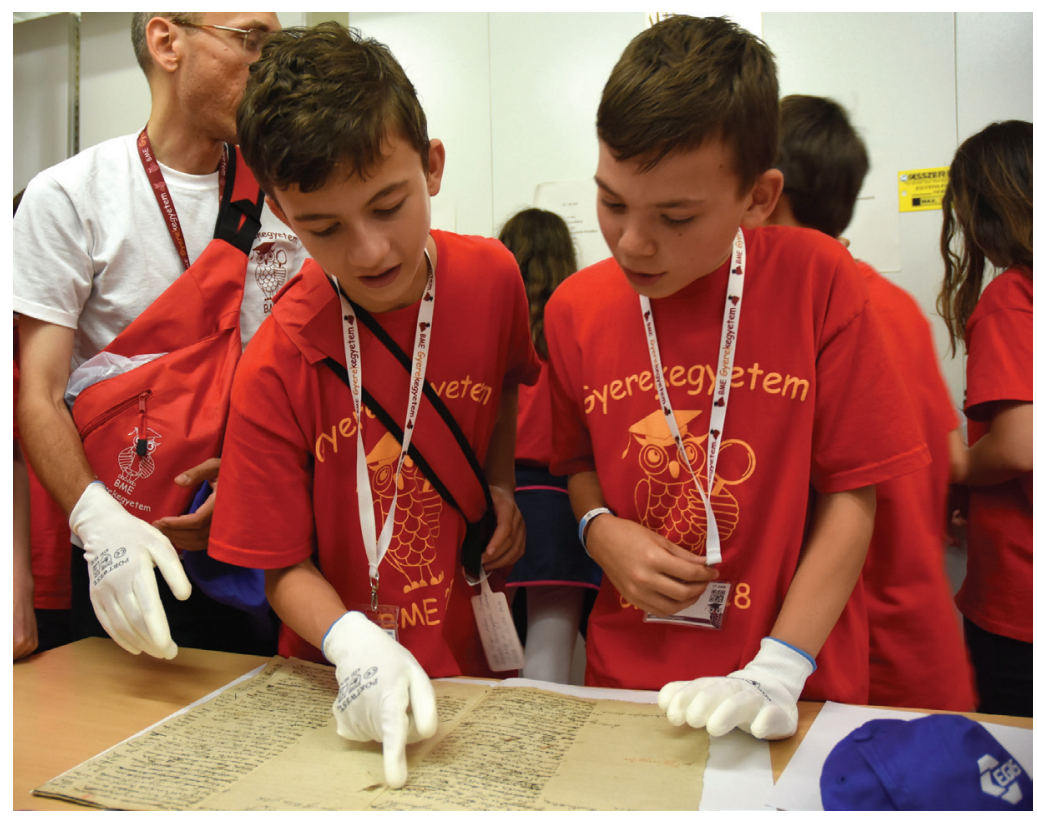

5. ábra

${ }^{14}$ Mit kívánnak a gyerekegyetemisták 2018-ban, milyen az az iskola, ahová jó járni?

1. Legyenek jó állapotú épületek, modern bútorok és nagy udvarok.

2. Legyen több tiszta mosdó és wc papír mindenhol.

3. Legyen ingyenes és jó a menzakaja, kedvesek a konyhás nénik.

4. Legyen free wifi és digitális tábla minden iskolában, kapjon mindenki tabletet a jegyzeteléshez.

5. Legyenek digitális tankönyvek, a hagyományosak pedig ne másoktól megörököltek, összefirkáltak.

6. Reggel később kezdődjön az iskola.

7. Legyenek rövidebbek és érdekesebbek az órák, cserébe keményebb a tanítás.

8. Osszák el a nyári szünet egy részét a tanévre.

9. A tanárok kapjanak több bért, legyenek rendesek és fegyelmezzenek jobban.

10. A tanítás és a számonkérés ne csak a lexikális tudásra épüljön, lehessen gondolkodni.

11. Hosszabb idő legyen a szakosodásra, ne kelljen minden tárgyat végig tanulni.

12. Ne legyen verekedés az iskolában, viselkedjenek a diákok is normálisan. 
Az idei terveink között az szerepel, hogy a szemináriumba kicsit több természettudományt vigyünk: levéltári mértékegységek, játék a papírral (súly, típus, tinta), a levéltári anyagot károsító fizikai és kémiai tényezők, a raktárban müködő oltógáz mechanizmusa stb.

Összefoglalásként úgy gondoljuk: nagy kihívás elé állítottuk magunkat, amikor gyakorlatilag tapasztalatok nélkül belevágtunk a levéltár-pedagógiai programjaink kidolgozásába és megvalósításába, cserébe viszont fantasztikus élményekkel lettünk gazdagabbak - reméljük, hogy a hozzánk látogatók is.

További információk és fotók a BME Levéltár honlapján és közösségimédia-felületein találhatók: www.omikk.bme.hu/leveltar, https://hu-hu.facebook. com/bmeleveltar, https://www.instagram.com/bme_leveltar.

\section{Rezümé}

A BME Levéltár a hagyományos közművelődési feladatok és színterek (kiállítások, levéltári napok stb.) mellett aktívan folytat levéltár-pedagógiai foglalkozásokat is az élményszerü ismeretszerzés és tanulás lehetőségének biztosítására. A Műegyetemen erre speciális lehetőséget biztosít a BME Gyerekegyetem elnevezésű nyári tudományos tábor. Emellett - a lehetőségek tükrében - levéltár-pedagógiai tevékenység más formában is megvalósítható a müegyetemi közgyüjteményben.

\section{Possibilities and experiences in archive pedagogy at the Budapest University of Technology and Economics}

Besides performing traditional cultural duties and offering its premises for events (exhibitions, open archive days, etc.), the Archives of the Budapest University of Technology and Economics (BME) makes efforts for providing learning opportunities based on personal experiences through archive pedagogical activities. The scientific summer camp called BME Children's University provides special possibilities for this at the University of Technolgy. There are also chances for other forms of archive pedagogical work at the public collections of the university.

BATALKA KRISZTINA levéltárvezető BME Levéltár 